\title{
Neutrophil Gelatinase Associated Lipocalin Urin sebagai Deteksi Dini Acute Kidney Injury
}

\author{
Siti Aizah Lawang, Antonius Pudjiadi, Abdul Latief \\ Departemen Ilmu Kesehatan Anak Fakultas Kedokteran Universitas Indonesia/Rumah Sakit Dr. Cipto \\ Mangunkusumo, Jakarta
}

\begin{abstract}
Latar belakang. Penelitian terkini fokus pada identifikasi biomarker yang lebih dini untuk acute kidney injury (AKI). Salah satunya adalah neutrophil gelatinase associated lipocalin (NGAL), protein 25 kDa yang merupakan potensial biomarker dini untuk AKI.

Tujuan. Melihat neutrophil gelatinase associated lipocalin (NGAL) sebagai biomarker dini untuk acute kidney injury (AKI).

Metode. Penelitian kualitatif dengan desain uji diagnostik. Pengambilan sampel secara cross sectional dan consecutive sampling pada 50 orang anak, terdiri atas 28 sepsis dan 22 sepsis berat di ruang rawat intensif anak di RS. Cipto Mangunkusomo Jakarta dan RS. Wahidin Sudirohusodo Makassar.

Hasil. Terdapat perbedaan sangat bermakna kadar NGAL urin dan kreatinin berdasarkan beratnya sepsis $(\mathrm{p}<0,001)$. Nilai rerata sepsis $132,93 \mathrm{ng} / \mathrm{mL}$ dan sepsis berat $2159,98 \mathrm{ng} / \mathrm{mL}$. Terdapat perbedaan bermakna antara beratnya AKI menurut kriteria RIFFLE dengan beratnya sepsis $(\mathrm{p}=0,013)$. Tidak terdapat hubungan bermakna antara kadar NGAL urin dengan kriteria RIFFLE ( $\mathrm{p}=0,173)$. Nilai sensitifitas NGAL urin $100 \%$ dan spesifisitas $63,63 \%$, positive predictive value $27,27 \%$, negative predictive value $100 \%$ dan area under curve (AuOC) 0,826.

Kesimpulan. Neutrophil gelatinase associated lipocalin (NGAL) dapat dipakai sebagai skrining AKI.

Sari Pediatri 2014;16(3):195-200
\end{abstract}

Kata kunci: neutrophil gelatinase associated lipocalin; sepsis, children

$A$ cute Kidney Injury (AKI) merupakan komplikasi yang sering dan berat pada pasien sepsis di ICU. Terlebih lagi, terdapat bukti kuat antara sepsis dan syok sepsis sebagai penyebab AKI pada pasien sakit kritis. Terhitung,

Alamat korespondensi:

Dr. Siti Aizah Lawang, Sp.A. RSUP Dr.Wahidin Sudirohusodo, Makassar, Sulawesi Selatan. Telp. (0411) 453534. E-mail: aizablawang@yahoo.co.id sekitar 50\% atau lebih pasien di ICU akan terjadi AKI dengan angka mortalitas yang tinggi. Penelitian the beginning and ending supportive therapy (BEST), yang mengevaluasi 54 rumah sakit yang tersebar di 23 negara, menemukan bukti bahwa sepsis adalah penyebab AKI paling sering pada pasien sakit kritis (47,5\%). Pada anak, angka kematian dengan sepsis menjadi $>10$ kali lipat apabila disertai acute renal failure. ${ }^{1,2}$ 
Saat ini, penentuan yang dipakai untuk penegakan diagnosis AKI adalah kriteria RIFFLE berdasarkan kreatinin serum. Namun, hal ini memiliki kelemahan karena merupakan marker yang lambat, meningkat setelah terjadi penurunan fungsi ginjal. Penelitian terkini fokus pada identifikasi biomarker yang lebih dini untuk AKI. Salah satunya neutrophil gelatinase associated lipocalin (NGAL) adalah protein $25 \mathrm{kDa}$ yang merupakan potensial biomarker dini untuk AKI.,4 Fungsi NGAL belum sepenuhnya diketahui. Peningkatan akan terjadi apabila sel dalam keadaan stres, misalnya infeksi, inflamasi, iskemia, dan neoplasma. Peran sebagai antibakteri juga dimiliki NGAL, berguna dalam pertumbuhan dan diferensiasi sel epitel tubulus ginjal. Pada keadaan terjadi kerusakan tubulus ginjal, kadar NGAL meningkat untuk menginduksi re-epitelisasi tubulus. ${ }^{5-7}$ Dari Penelitian Nickolas $\mathrm{dkk}^{8}$ didapatkan hasil cut off point NGAL $130 \mu \mathrm{g} / \mathrm{g}$, sensitivitas 90\% (95\%CI 0,73-0,98) dan spesifisitas 99,5\% (CI, 0,99-1,00).

\section{Metode}

Studi penelitian uji diagnostik dengan cara cross sectional dan consecutive sampling. Penelitian dilaksanakan di ruang rawat intensif anak RS Cipto Mangunkusumo Jakarta dan RS. Wahidin Sudirohusodo Makassar. Penelitian mulai dilakukan bulan Desember 2013 sampai dengan Juni 2014. Populasi target adalah anak dengan sepsis yang dirawat di ruang rawat intensif anak dan instalasi gawat darurat. Kriteria inklusi adalah usia pasien 1 bulan -16 tahun, didiagnosis sepsis, dan orangtua pasien bersedia ikut serta dalam penelitian. Kriteria eksklusi adalah anak yang sebelumnya pernah menderita insufisiensi renal, penggunaan obat nefrotoksik sebelum penelitian, penyakit ginjal kronis, infeksi saluran kemih, inflamasi ginjal, dan anak yang anuria. Diperlukan jumlah 50 sampel dengan perkiraan besar sampel untuk uji diagnostik dengan keluaran sensitifitas.

\section{Cara kerja}

Pasien yang memenuhi kriteria inklusi diambil sebagai subjek penelitian. Selanjutnya, subjek diberi penjelasan, diminta persetujuan tertulis, dan diwawancarai tentang riwayat perjalanan penyakit. Setelah itu, subjek dilakukan pemeriksaan fisik dan penunjang. Dicatat data dasar, riwayat penyakit terdahulu, diagnosis utama saat masuk, (sepsis, sepsis berat/MODS, syok sepsis). Dilakukan pemeriksaan fisik, berupa tanda vital dan pemeriksaan laboratorium, kreatinin serum, dan NGAL urin. Pemeriksaan NGAL urin diambil $30 \mathrm{cc}$, melalui mid stream atau per kateter. Urin ditampung dalam pot urin atau urine collector, 6 cc darah vena untuk kreatinin. Kadar NGAL urin dilihat berdasarkan derajat sepsis, yaitu sepsis dan sepsis berat. Dibandingkan peningkatan NGAL urin dan kriteria RIFFLE. Dihitung sensitivitas, spesifisitas, dan kurva ROC dari NGAL urin. Pengolahan data digunakan SPSS 11,5 dengan analisis univariat untuk deskripsi karakteristik data penelitian. Uji Anova digunakan untuk analisis perbedaan rerata NGAL urin berdasarkan beratnya sepsis. Uji $X^{2}$ test digunakan untuk analisis hubungan antara beratnya sepsis dengan kriteria RIFFLE dan berat ringannya penyakit. Dicari nilai sensitifitas dan spesifisitas dari urin NGAL dan kurva ROC.

Penelitian ini telah mendapat persetujuan dari Komisi Etik Penelitian Biomedis pada Manusia Fakultas Kedokteran Universitas Indonesia.

\section{Hasil}

Limapuluh pasien sepsis anak yang memenuhi kriteria penelitian, terdiri atas 28 sepsis dan 22 sepsis berat. Terdapat 13 sampel penelitian yang dilakukan di RS. Cipto Mangunkusomo dan 37 sampel di RS. Wahidin Sudirohusodo. Karakteristik subjek penelitian tertera pada Tabel 1 dan 2.

Tabel 1. Frekuensi subjek menurut jenis kelamin, penyakit, dan kategori sepsis

\begin{tabular}{lcc}
\hline Karakteristik & Frekuensi (n) & Persen (\%) \\
\hline Jenis kelamin & & \\
Laki-laki & 28 & 56 \\
$\quad$ Perempuan & 22 & 44 \\
Diagnosis & & \\
$\quad$ Non bedah & 30 & 60 \\
$\quad$ Bedah & 20 & 40 \\
Kategori sepsis & & \\
Sepsis & 28 & 56 \\
Syok sepsis & 22 & 44 \\
\hline
\end{tabular}


Tabel 2. Karakteristik subjek penelitian

\begin{tabular}{lc}
\hline Karakteristik & Nilai \\
\hline Umur (bulan) & \\
Rerata & 47,14 \\
Simpang baku & 51,20 \\
Minimum & 1 \\
Maksimum & 167 \\
Kreatinin serum(umol/L) & \\
Rerata & 59,82 \\
Simpang baku & 69,47 \\
Minimum & 8,84 \\
Maksimum & 291,72 \\
NGAL urin (ng/mL) & \\
Rerata & 1024,25 \\
Simpang baku & 1699,8 \\
Minimum & 1,33 \\
Maksimum & 6353,21 \\
\hline
\end{tabular}

Di antara 50 pasien sepsis yang ikut dalam penelitian ditemukan 28 sepsis dan 22 syok sepsis. Perbedaan nilai rata-rata NGAL urin dan kadar kreatinin tertera pada Tabel 3.

Hubungan antara beratnya sepsis dengan kriteria RIFFLE tertera pada Tabel 4.

Limapuluh pasien yang sepsis tidak ada yang mengalami AKI, sedangkan pada sepsis berat, 6 orang mengalami AKI. Hubungan antara kadar NGAL urin dengan kriteria RIFFLE tertera pada Tabel 5.

Nilai sensitifitas dan spesifisitas NGAL

Dengan memakai cut off point 1447,01, hasil tabel 2x2 tertera pada Tabel 6 .

Tabel 3. Kadar NGAL urin dan kreatinin serum berdasarkan beratnya sepsis

\begin{tabular}{|c|c|c|c|c|c|}
\hline \multirow{2}{*}{ Diagnosis } & \multirow{2}{*}{$\mathrm{n}$} & \multirow{2}{*}{ Rerata } & \multirow{2}{*}{ SD } & \multicolumn{2}{|c|}{$95 \% \mathrm{CI}$} \\
\hline & & & & Lower & Upper \\
\hline \multicolumn{6}{|c|}{ Kadar NGAL urin* } \\
\hline Sepsis & 28 & 132,93 & 272,73 & $-2816,44$ & $-1239,80$ \\
\hline Sepsis berat & 22 & 2159,98 & 2057,48 & $-2028,12$ & $-1111,11$ \\
\hline \multicolumn{6}{|c|}{ Kreatinin serum** } \\
\hline Sepsis & 28 & 0,37 & 0,37 & $-1,101$ & -287 \\
\hline Sepsis berat & 22 & 1,06 & 1,06 & $-1,16$ & -223 \\
\hline
\end{tabular}

$\mathrm{df}=49 ;{ }^{*} \mathrm{p}=0,000(\mathrm{p}<0,001) ;{ }^{* *} \mathrm{p}=0,001(\mathrm{p}<0,05)$

Tabel 4. Distribusi pasien sepsis berdasarkan kriteria RIFFLE

\begin{tabular}{lcccc}
\hline Kategori & \multicolumn{3}{c}{ Riffle } & Total \\
\cline { 2 - 4 } & Failure & Injury & Normal & \\
\hline Sepsis & 0 & 0 & 28 & 28 \\
Sepsis berat & 4 & 2 & 16 & 22 \\
Total & 4 & 2 & 44 & \\
\hline $\mathrm{d}=4$ & $\mathrm{p}=0,013(\mathrm{p}<0,05)$ & &
\end{tabular}

Tabel 5. Hubungan antara kadar NGAL urin dengan kriteria RIFFLE

\begin{tabular}{lccccc}
\hline & $\mathrm{n}$ & Rerata & SD & Minimum & Maksimum \\
& & & & & \\
\hline Normal & 44 & 870,32 & 1710,10 & 1,33 & 6353,21 \\
Injury & 2 & 1447,01 & 1503,02 & 384,21 & 2509,81 \\
Failure & 4 & 2505,90 & 1063,12 & 1729,49 & 4007,84 \\
\hline
\end{tabular}


Tabel 6. Tabel 2x2 RIFFLE dan NGAL RIFFLE

\begin{tabular}{lccc}
\hline & AKI $(+)$ & AKI $(-)$ & total \\
\hline AKI $(+)$ & 6 & 16 & 22 \\
AKI $(-)$ & 0 & 28 & 28 \\
\hline total & 6 & 44 & 50 \\
\hline
\end{tabular}

Sensitifitas : $a /(a+c)=6 /(6+0)=100 \%$

Spesifisitas : $\mathrm{d} /(\mathrm{b}+\mathrm{d})=28 /(16+28)=63,63 \%$

Positive Predictive Value $: \mathrm{a} /(\mathrm{a}+\mathrm{b})=6 /(6+16)=27,27 \%$

Negative Predictive Value: $\mathrm{d} /(\mathrm{c}+\mathrm{d})=28 /(28+0)=100 \%$

Nilai AuOC adalah 0,826

\section{ROC Curve}

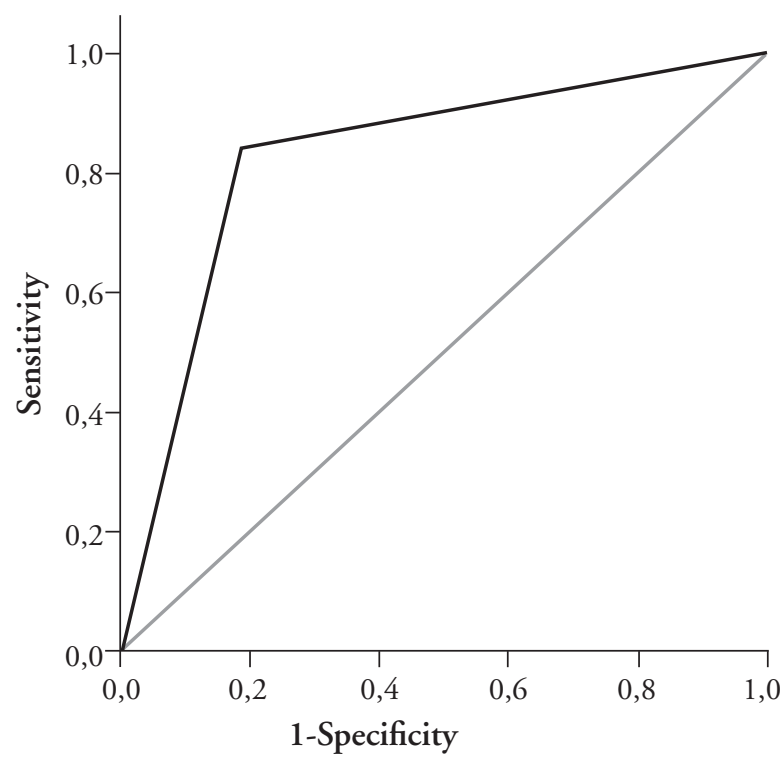

Diagonal segments are produced by ties

Gambar 1. Kurva ROC

\section{Pembahasan}

Pada semua pasien sepsis didapatkan nilai rerata kreatinin serum 59,82 $\pm 69,47 \mathrm{umol} / \mathrm{L}$. Nilai ini lebih rendah dari nilai kreatinin serum pasien sepsis AKI dari penelitian Morimatsu $\mathrm{dkk}^{9}$ dengan hasil $142 \pm 94-$ $191 \mathrm{umol} / \mathrm{L}$ dan didapatkan nilai rerata NGAL urin $1024,25 \pm 169,9$ untuk semua pasien sepsis. Nilai ini lebih tinggi daripada hasil yang didapatkan dari Wheeler $\mathrm{dkk}^{10}$ dengan nilai median anak yang SIRS/ sepsis $107,5 \mathrm{ng} / \mathrm{mL}$ dan syok sepsis $302 \mathrm{ng} / \mathrm{mL}$ yang meneliti kadar urin NGAL pada pasien yang syok septik.

Terdapat perbedaan kadar NGAL urin berdasarkan beratnya sepsis dengan nilai rerata sepsis $132,93 \mathrm{ng} / \mathrm{mL}$ dan 2159,98 ng/mL sepsis berat. Apabila digunakan cut of point $130 \mathrm{ug} / \mathrm{g}$ dari penelitian Nickolas $\mathrm{dkk}^{8}$ sebagai batas normal NGAL urin, peningkatan NGAL urin sudah terlihat pada tahap sepsis. Semakin berat sepsis maka kadar NGAL urin semakin meningkat. Hal tersebut mungkin disebabkan perjalanan sepsis yang semakin berlanjut sehingga terjadi AKI failure. Hasil ini lebih tinggi dibandingkan dengan hasil penelitian Wheeler $\mathrm{dkk}^{10}$ yang memiliki median $107 \mathrm{ng} / \mathrm{mL}$ kadar NGAL pasien dengan SIRS, sedangkan yang septik syok median $302 \mathrm{ng} / \mathrm{ml}(\mathrm{p}<0,001)$. Penelitian Wheeler juga menyebutkan kadar NGAL akan meningkat dalam 24 jam pertama setelah terjadinya syok sepsis dan akan tetap meningkat selama 3 hari pada pasien kritis yang akhirnya akan menjadi AKI. Peningkatan nilai yang lebih tinggi, terutama pada pasien yang sepsis berat, karena selain telah terjadi gangguan hemodinamik berupa syok juga kemungkinan sudah terjadi AKI sepsis.

Terdapat perbedaan kadar kreatinin berdasarkan beratnya sepsis. Namun, apabila dilihat kadar kreatinin pada pasien sepsis dan sepsis berat dari hasil statistik berbeda. Pada tahap sepsis, kadar kreatinin masih dalam batas normal dan kenaikan kreatinin terlihat sedikit meningkat pada sepsis berat. Hal tersebut berbeda dengan kadar kenaikan NGAL yang sudah terlihat pada tahap sepsis. Sesuai dengan hasil penelitian terdahulu yang mengatakan bahwa kreatinin serum adalah marker yang lambat karena muncul setelah terjadi penurunan fungsi ginjal/penurunan glomerular filtration rate (GFR) sehingga menghambat deteksi AKI secara dini.

Terdapat perbedaan antara beratnya AKI menurut kriteria RIFFLE dengan beratnya sepsis. Namun, pada kategori sepsis tidak terjadi AKI menurut kriteria RIFFLE. Sementara itu, pada sepsis berat, hanya 6 anak yang telah terjadi AKI, yaitu empat orang failure dan dua injury. Hal ini dikarenakan, kriteria RIFFLE berasal dari kreatinin serum yang lebih lambat mengalami peningkatan sehingga pada kondisi berat, baru kreatinin akan meningkat. Akan tetapi, jumlah AKI ini sangat sedikit sehingga diperlukan penelitian dengan jumlah sampel yang lebih besar.

Tidak terdapat korelasi atau terjadi korelasi negatif antara kadar NGAL urin dan kriteria RIFFLE. Jadi, menurut kriteria RIFFLE masih normal belum terjadi AKI, tetapi NGAL sudah tinggi. Hal ini dikarenakan, peningkatan NGAL lebih dulu terjadi dibandingkan kreatinin (RIFFLE). Peningkatan kadar NGAL urin 
ini seiring dengan perburukan AKI. Hasil tersebut lebih tinggi dibandingkan dengan penelitian Zappitelli dkk. ${ }^{11}$ Hal tersebut mungkin disebabkan penelitian yang dilakukan oleh Zappitelli tidak dilakukan pada pasien sepsis yang akan menambah faktor risiko peningkatan NGAL urin. Sepsis merupakan salah satu faktor peningkatan NGAL urin sesuai dengan penelitian Morimatsu dkk. ${ }^{12}$ Penelitian Morimatsu "Plasma dan urin NGAL pada sepsis versus non sepsis AKI pada pasien kritis" mendapatkan hasil NGAL urin pasien sepsis AKI lebih tinggi apabila dibandingkan dengan AKI tanpa sepsis. ${ }^{13}$

Untuk membuat Tabel $2 \times 2$, peneliti mengambil cut off point 1447,01 berdasarkan Tabel 5 tentang hubungan kadar NGAL dengan kriteria RIFFLE pada RIFFLE injury yang artinya sudah terjadi AKI, didapatkan nilai 1447,01 . Dari hasil perhitungan sensitifitas dan spesifisitas NGAL urin didapatkan sensitifitas $100 \%$, spesifisitas $63 \%$, positive predictive value $27,27 \%$, dan negative predictive value $100 \%$. Sensitifitas $100 \%$ berarti kemungkinan hasil uji diagnostik ini akan positif apabila dilakukan pada kelompok subjek yang sakit. Spesifisitas 63\% artinya terdapat 63\% kemungkinan hasil uji diagnostik ini akan negatif apabila dilakukan pada subjek yang sehat. Negative predictive value 27,27\% adalah kemungkinan uji NGAL urin yang menyatakan bahwa seseorang pasien benar-benar tidak menderita AKI. Sementara itu, positif predictive value $100 \%$ adalah besarnya kemungkinan uji NGAL urin yang menyatakan bahwa seseorang benar-benar mengidap AKI. Ini artinya, NGAL urin mempunyai sensitifitas yg sangat tinggi, tetapi spesifisitas tidak terlalu tinggi. Di samping itu, keakuratannya untuk menyatakan seseorang tidak mengidap AKI sangat tinggi dengan nilai negative predictive value $100 \%$. Karena sensitifitasnya sangat tinggi sampai $100 \%$, NGAL ini paling baik untuk skrining, tetapi kurang baik untuk diagnostik karena spesifisitasnya hanya $63,63 \%$. Hal tersebut mungkin disebabkan jumlah sampel yang sedikit dan pasien yang mengalami gagal ginjal tidak ada yang tahap risk sehingga nilai cut of point yang dipakai cukup tinggi $(1447 \mathrm{ng} / \mathrm{mL})$.

Hasil tersebut berbeda dengan penelitian Nickolas $\mathrm{dkk}^{8}$ dengan nilai cut off point kreatinin $130 \mu \mathrm{g} / \mathrm{g}$, sensitifitas, dan spesifisitas NGAL urin untuk mendeteksi AKI 90\% dan 99,5\% dan nilai positive dan negative likelihood ratio 181,5 (CI, 58,33 to 564,71 ) dan 0,10 (CI, 0,03 to 0,29$)$. Hasil penelitian ini mendapatkan area under curve ROC (AuOC) 0,826 yang artinya tes ini bagus untuk dipakai.

Keterbatasan penelitian adalah sampel yang sedikit, dalam waktu \pm 6 bulan hanya terkumpul 50 sampel, dan jumlah pasien yang mengalami AKI juga sangat sedikit, dari 6 pasien AKI tidak ada pasien yang mengalami AKI tahap risk. Dengan demikian, perlu penelitian lanjutan mengenai NGAL urin pada sepsis dengan populasi yang lebih besar. Diperlukan juga penelitian yang bersifat kohort prospektif dengan pemeriksaan NGAL urin secara serial untuk melihat NGAL urin sebagai petanda terjadinya AKI pada pasien sepsis.

\section{Daftar pustaka}

1. Goldstein SL. Acute kidney injury in children and its potential consequences in adulthood. Blood Purif 2012;33:131-7.

2. Alatas H. Gagal ginjal akut. Dalam: Noer S, Asmaningsih N, Subandiyah K, dkk. Kompendium nefrologi anak. Jakarta: UKK Nefrologi IDAI; 2011.h.207-214.

3. Bagshaw SM, George C, Bellomo B. early acute kidney injury and sepsis: a multicentre evaluation. Crit Care 2008:1-9.

4. Huber W, Saugel B, Schmid RM, Gussmann W. Early detection of acute kidney injury in sepsis: how about NGAL? CLI, 2012. Diakses pada 13 Oktober 2014. Didapat dari: http://www.medizin.uni-tuebingen.del kinder/delabteilungen/neonatologie/Geschaeftsbericht\% 202012.pdf.

5. Uttenthal O. NGAL: a marker molecule for the distress kidney. J CLI 2005:1-2.

6. Bolignano D, Donato V, Coppolino G, Campo S, Buemi A. Neutrophil gelatinase-associated (NGAL) as a marker kidney damage. Am J Kidney Dis 2008;52:595-605.

7. Clerico A, Galli C, Fortunato A, Ronco C. Neutrophil gelatinase-associated lipocalin (NGAL) as biomarker of acute kidney injury: a review of the laboratory characteristic and clinical evidences. Clin Chem Lab Med 2012;50:1505-17.

8. Nickolas TL, O'Rourke MJ, Yang J. Sensitivity and specificity of single emergency department measurement of urinary neutrophil gelatinase associated lipocalin for diagnosing acute kidney injury. Ann Intern Med 2008;148:810-819.

9. Morimatsu H, Egi M, amico GD. Plasma and urine neutrophil gelatinase-associated lipocalin in septic versus 
non-septic acute kidney injury in critical illness. Intensive Care Med 2010;36:452-61.

10. Wheeler DS, Devarajan P, Ma Q, Harmon K. Serum neutrophil gelatinase-associated lipocalin (NGAL) as a marker of acute kidney injury in critically III children with septic shock. Crit Care Med 2008;36:1297-303.

11. Zappitelli M, Wasburn KK, Arikan AA. Urine neutrophil gelatinase-associated lipocalin is an early marker of acute kidney injury in critically III children: A prospective
Cohort Study. Crit Care 2007;11:1-11.

12. Morimatsu H, Egi M, amico GD. Plasma and urine neutrophil gelatinase-associated lipocalin in septic versus non-septic acute kidney injury in critical illness. Intensive Care Med 2010;36:452-61.

13. Lentini P, Cal MD, Clemnti A, D’Angelo A. Sepsis and AKI in ICU patients: the role of plasma biomarker. Handawi Publishing Corporation. Crit Care Res Pract 2012;1-5. 